\title{
14. The Lives of the Characters in DICKENSIAN
}

\author{
Luke McKernan
}

On Christmas Eve, sometime during the 1840s, in a warren of London streets, a number of people are facing crises in their lives. Amelia and Arthur Havisham have attended their father's funeral and have returned to their home, Satis House. Outside, the moneylender, Jacob Marley, scowls at the cheerful Mrs. Gamp, then sends a boy with a message to Fagin. He runs past Mr. and Mrs. Bumble as he does so. Elsewhere, Marley's business partner, Ebeneezer Scrooge, passes by the Old Curiosity Shop, which has a notice saying it is closed owing to illness. Inside, a dangerously ill Little Nell is tended to by her grandfather and a bibulous Mrs. Gamp. At Scrooge and Marley's office, their assistant learns that there has been a deduction in his wages, but prompt payment of a loan is still expected of him. Sensing that he must move quickly to gain a financial advantage, Scrooge asks for the Old Curiosity Shop account. At Satis House, Amelia is comforted by her good friend, Honoria Barbary, whose hapless father is facing financial ruin. Arthur Havisham starts to plot against his sister, with an accomplice, Compeyson. In his den, Fagin tells the prostitute, Nancy, that she has an appointment with Jacob Marley that evening. She shivers with fear ... ${ }^{1}$

The opening episode of the British television series DiCKENSIAN introduced viewers to the back stories of characters from Charles Dickens's novels. These stories then unfolded and intertwined over the series. The roots of Great Expectations, Bleak House, Oliver Twist, A Christmas Carol, The Old Curiosity Shop and others were imagined as having come from a single narrative source, a journey by suggestion into the mind of Charles Dickens, reinventing his oeuvre as a Balzacian Comédie Humaine, with interlocking characters across the different novels, revealing a fully realized alternative world. The figure that initially pulls all these characters and their personal stories together is Jacob Marley. By the end of the first episode, we see that almost everyone has good reason to wish him dead, and then his body is found lying in an alley. The mystery of who killed him must then, of course, be investigated by Inspector Bucket, the detective from Bleak House.

DiCKENSIAN was the invention of British television scriptwriter, Tony Jordan, creator or cocreator of such popular series as HuSTLE (2004-2012) and LIFE ON MARS (2006-2007). He is best known as the lead writer of nearly 
three decades of the BBC soap opera EASTENDERS (1985- ).Jordan has written that his interest in Charles Dickens as source material began when he was invited to present an episode of the BBC series THE SECRET LIFE OF BOOKS (2014- ), on Great Expectations (Jordan 2014). The program explored Dickens's art through the eyes of an expert soap-opera writer: the serial nature of publication, the use of cliff-hangers, the interwoven personal stories, and the high appeal to a mass audience. Inspired by a sense of affinity, Jordan then set about writing Dickensian, a twenty-part series of 30-minute episodes produced by his own Red Planet Pictures. The connection between Dickens and soap opera has been made on many occasions. Jordan set out to prove his case, but rather than adapt any of Dickens's works - as has often been done on British television - he would appropriate and mix aspects of them all. In the world of DiCKENSIAN, Fagin (Oliver Twist) rubs shoulders with Scrooge (A Christmas Carol), Inspector Bucket (Bleak House) crosses with Bob Cratchit (A Christmas Carol), a fawning Mr. Bumble (Oliver Twist) plays host to Gradgrind (Hard Times), and Amelia Havisham (known only as "Miss Havisham" in Great Expectations: her first name is Jordan's invention) is best friends with Honoria Barbary (Bleak House). The three main narratives are the Marley murder, the Barbary bankruptcy, and the false wooing of Miss Havisham. However, several smaller stories unfold: the Bumbles' hapless attempts at social advancement, a romance between Peter Cratchit and Little Nell, and Sikes freeing Nancy from Fagin's control (Oliver Twist). In addition, there are many wry references to other parts of the Dickens canon: the orders for an unseen Mr. Pickwick being taken at the Three Cripples pub, Honoria working at Mantalini's dressmakers (as featured in Nicholas Nickleby), Uriah Heep named as Jaggers's secretary (combining David Copperfield with Great Expectations), and Oliver Twist asking for more. It begins with A Christmas Carol ("Marley was dead: to begin with. There is no doubt whatever about that"). It ends at the point where Great Expectations could begin, the jilted bride asserting that, from this point onward, time for her would stand still.

What could merely have been a clever intellectual exercise revealed itself to be an original and ingenious entertainment. You could see the delight in the actors' eyes at the quality of the writing and the piquancy of the situations in which they found themselves. It is arguable that twenty episodes was too long, with the series' structural logic torn between the endless unfolding of a soap opera and the expected conclusion of a timelimited narrative, the difference between what Robert C. Allen (1995) in his studies of the soap-opera form defined as open and closed serials (the various narratives are all resolved by the final episode, featuring Amelia 
Havisham's disastrous wedding day). At its weakest, DiCKENSIAN overplayed the obvious (in particular, the Miss Havisham strand). At its best, it was as good a television drama as Britain had ever known.

In particular, Episode 16, in which Honoria Barbary (played by Sophie Rundle) gives birth, aided only by her embittered sister, Frances (Alexandra Moen), was among the best 30 minutes of televised drama that this writer has ever seen. While previous episodes had criss-crossed over the series' different story strands in the usual soap-opera manner, this episode concentrated on the one story alone with remorseless intensity and extraordinary effect, from the panic leading up to the birth to the shock of the dilemma Frances puts herself in at the end of the episode (the outcome of which would be known only to those who had read Bleak House). In writing, pacing, performance, lighting, decorative detail, and use of our knowledge of the characters' pasts to create tension and force climax, this was a program to hold up as the best of what the medium can achieve. It was also a convincing argument for why literature belongs on the screen. ${ }^{2}$

It can often seem that we are growing bored of the classics, and must mangle them to sustain our jaded appetites. Sequels and prequels, modernizations, parodies, and revered characters battling with the living dead - as in Pride AND Prejudice ANd Zombies (2016) - seem to express an ennui, an admission that no one has the patience to read novels any more, or else frustration at some great novelists not having written more than they did.

On its announcement, DICKENSIAN sounded as though it was going to be yet another example of this syndrome, a desperate stirring of the ingredients to try and come up with something new to attract ratings. Instead, it showed that there was life in these characters beyond that set down on the page by Charles Dickens - and that reimagining the classics need not be sacrilege, but can be insightful, and even necessary, when it is done well. It showed how characters on the page remain in our minds because they live convincing lives. Those lives can be sustained in other forms, where there is enough imagination and belief. Indeed, to sustain those convincing lives, it may be as important to reimagine such stories as it is to read them. We can no longer read past works as those in the past did, because we are different people (different in terms of outlook and our sense of time). Nevertheless, if those works' status as art is to endure, then reimagining them becomes an essential part of how we continue to tell them. This, however, does not mean Little Dorrit and the undead - it implies getting inside the mind of the author and plucking out something new along with the familiar. This is exactly what Tony Jordan and his team did: they visualized "the mind of Charles Dickens" - and, in doing so, recalled Robert William Buss's painting 
Dickens's Dream (1875), which is well known in Britain and which showed the author surrounded by a phantasmagoric gathering of his "characters."

DiCKENSIAN was an artistic success, but audiences showed a mixed response. The first two episodes were broadcast on BBC One, separated by an hour, on December 26, 2015. The timing was completely appropriate, but thereafter the series suffered from erratic scheduling. The time slots of the episodes appeared to change each week, making it difficult for audiences to get into the program's routine in the same manner as they would with a conventional soap opera, which had clearly been the producers' intention. ${ }^{4}$ This seems to have been caused partly by uncertainty on the part of the BBC as to how best to present the series, but also to some degree a consequence of waning audience interest early on. The first two episodes attracted an audience of 5 million and 4.3 million respectively (excluding later catch-up figures), but dropped steadily thereafter, down to two million by the time of the twentieth episode (Martinson 2016).

Every effort had been made to give the series a broad appeal. The production values were high, with a reported $£ 10 \mathrm{~m}[\$ 14 \mathrm{~m}]$ being spent, including the construction of a large single-set boasting 27 two-storey buildings and a 90-meter [98yd] cobbled street that placed the Dickensian characters in close proximity to one another (Burrell 2015). The cast was particularly strong: Stephen Rea (Inspector Bucket), Tuppence Middleton (Miss Havisham), Anton Lesser (Fagin), Caroline Quentin (Mrs. Bumble), Pauline Collins (Mrs. Gamp), Omid Djalili (Mr. Venus) and Peter Firth (Jacob Marley) among them. The faces were as familiar as the characters.

Yet something, beyond the troublesome scheduling, did not quite work. Critics were, for the most part, generous with their praise, admiring the wit of the conception and the style of its realization. Still, some felt a nagging sense of an uncertainty of purpose, perhaps best expressed by Ben Dowell in Radio Times:

[T] he first and most obvious question to ask is this: they may have the same names and look like they are described in the books but who are these people? Can they really be said to be Dickens characters? The great Victorian novelist invented these richly drawn characters to fit into the novels he wrote. He was a storyteller, first and foremost, someone who wrote episodic narratives driven by the unstoppable force of his ingeniously-crafted [sic] plots. He populated his books with amazing characters, of course, but tearing them away from their stories is to essentially denude them of their essential life and being. [...] If I am quite honest I couldn't see the point of this exercise which failed to teach us 
anything new about any of Dickens' characters, or allowed them to develop in any meaningful way. (2015)

For Dowell, the problem was that DickEnsian wasn't Dickens. The characters existed within the fictions that had been originally created for them. They did not have, or could not have, exterior lives. The exercise was clever, but added nothing to Dickens's expression of those people, whose reason for being existed solely within his pages.

While this is an understandable line of argument, it is fundamentally false. Writers do not own the characters that they create, nor the works in which such characters may be found. Of course, in a legal sense, such ownership may exist. Charles Dickens raged against the American "pirates" who republished or adapted his original creations, in the absence of any international copyright legislation (such as was first introduced in 1886 with the Berne Convention). Copyright law identifies particular rights of ownership that lie with the originator of a creative work, but it is a different matter when one considers how people read. Ownership of the play of a creative work upon the imagination lies with any individual reader (or viewer), and more than stories, we feel that we own the characters. If the author has imbued any life in them at all, then our imaginations must flesh out what is presented to us on the printed page. We want to know what will happen to them; we want to know where they came from. They lead convincing lives.

This is the sentimental tendency against which the critic, L.C. Knights, famously railed in his, How Many Children Had Lady Macbeth? (1933). A great work of fiction, Knights argued, is not driven by the personal but by the thematic. Characters exist inasmuch as they support the governing ideas. Speculation on their lives beyond that which was the express purpose of the artist is fatuous, as critical enquiry. But that does not stop the reader from such speculation, nor the writer who might want to capitalize on such enthusiasm. Tony Jordan expressed such enthusiasm when he considered Miss Havisham:

I have always been fascinated by the character of Miss Havisham - this mad woman in a wedding dress and veil, sitting at the table, jilted on the day of her wedding, an event she found so traumatic that she never took off her wedding dress. We've all seen that image and we all know it, so I was interested in how she got to be that woman. What was she like as a young woman and in love? Did she laugh? Who was she? What did she care about? So I decided that was one of the first stories I wanted to tell, 
it was exciting because nobody had ever seen the young Miss Havisham before - it was then that I knew I had something. (2015a)

Prequels and sequels to the classics, from Mary Cowden Clarke's series The Girlhood of Shakespeare's Heroines, to Jean Rhys's Wide Sargasso Sea (a prequel to Jane Eyre), to the mini-industry that is the Jane Austen sequel novel (such as Emma Tennant's Pemberley: Or Pride and Prejudice Continued), all betray the urge to extend our belief. The film industry is sustained by sequels and prequels that recapitulate narrative elements and particular characters that a mass audience will pay to see once again.

The digital era has created a thirst for the extension of narrative and character, and provided the means to achieve this online, for example, fan fiction, in which the fans of a creative work publish their own stories developed out of the original characters or settings. Some authors have embraced this development of their imaginative originals (J.K. Rowling), while others have reacted angrily against it (Anne Rice, George R.R. Martin). Either way, the evidence is clear: stories and characters have lives of their own. We appropriate them through our affection. Once you have asked how many children Lady Macbeth had, someone will want to know the answer - and someone will set out to provide that answer. Lady Macbeth's other life matters.

Various commentators have suggested a link between DickENSIAN and fan fiction, though Tony Jordan denies any connection. However, the fundamental motivation was the same. In the same interview, Jordan says that "it had to be about taking ownership of the characters, after all Dickens never wrote a scene between Scrooge and Fagin, or between a young Miss Havisham and Martha Cratchit, but I had to do just that" (2015b). The compulsion lay in that sense of ownership. This derives, fundamentally, from the sense of entitlement that the sharing of content over the Internet has engendered. It is not just about the assertion of a postcopyright age where former boundaries no longer apply. It is about a release of the imagination created by opportunity. The age of the copy is producing stories that must exist because they are copies.

Dickens himself was said to have appropriated characters, turning people that he met into figures on a page. It is a common accusation, but except for certain romans à clef, it is a misleading one. Peter Ackroyd writes of this tendency:

Dickens used certain salient characteristics of the people whom he met or knew, but there are very few instances when he simply transcribed what 
he had seen and heard onto the page. The novelist's art is not of that kind: Dickens perceived a striking characteristic, or mood, or piece of behaviour, and then in his imagination proceeded to elaborate upon it until the "character" bears only a passing resemblance to the real person. In his fiction Dickens entered a world of words which has its own procedures and connections, so that the original "being" of any individual is subsumed into something much larger and generally much more conclusive. (1990, 65)

As with Dickens and real life, so it was with Tony Jordan and Dickens. Salient characteristics have been appropriated to build a fresh creative work. DiCKENSIAN is not Dickens; it is Dickensian. It takes ownership of the characters and settings to make sense of them in a world of the new writer's invention.

In an essay on The Mystery of Edwin Drood, V.S. Pritchett considered the meaning of the word "Dickensian" in relation to style and characters. Arguing that much of what is understood as Dickensian in style is an inheritance from Sterne, Smollett, and Richardson, Pritchett looked instead at Dickens's people:

$[\mathrm{T}]$ he distinguishing quality of Dickens's people is that they are solitaries. They are people caught living in a world of their own. They soliloquise in it. They do not talk to one another; they talk to themselves. The pressure of society has created fits of twitching in mind and speech, and fantasies in the soul. [...] In how many of that famous congress of "characters" Micawber, Barkis, Moddles, Jingle, Mrs. Gamp or Miss Twitterton: take them at random - and in how many of the straight personages, like Jasper and Neville Landless in Edwin Drood, are we chiefly made aware of the individual's obliviousness of any existence but his own? $(1998,85)$

For Pritchett, Dickens's characters are "all out of touch and out of hearing of each other, each conducting its own inner monologue," a disassociation he identifies as having its roots in "the fright of childhood" (1998, 90). Quite the opposite is the case with DiCKENSIAN. In this world, which is the world of the soap opera, existence is defined by the individuals' relations to others. They form an organic piece, no element of which has meaning except for the way in which it impacts on the fate of the other elements. The rapid cutting from one story element to another reinforces the sense of characters bound together by an overarching narrative whose direction, indeed existence, they do not sense - for the most part. Soap operas are sustained dramatically by the idea of the community that they portray, even if Tony Jordan's hugely 
successful EASTENDERS regularly challenges the idea of community as something that is still valid in modern times (the characters, particularly in the early years of EASTENDERS, would speak of better, more communal times in the past - maybe as far back as the 1840s) (Geraghty 1995). If there is a childhood root in this to complement that identified in Dickens by Pritchett, then it is the urge to belong. However, this does not lie in the writer but in the readership, who yearn to own what they see.

There are moments when a realization of community and shared destiny are made apparent, most notably when Nancy (played by Bethany Muir) sings at the Three Cripples, on occasions where many of the leading characters have gathered in that same place (a pub, the Queen Vic, is the communal centerpiece of EASTENDERS). This occurs at the end of Episode 10 and, especially, at the end of the final episode, where her rendition of "I dreamt I dwelt in marble halls" touches every heart within, the camera panning from face to face, as all set aside private troubles and find themselves caught up in the collective sentiment. Beyond, but at the same time, Miss Havisham weeps at the table with her wedding feast; Arthur Havisham, his selfish plans in ruins, prepares to commit suicide; the ghostly voice of Marley is heard by Scrooge; and Oliver Twist is taken in by the Artful Dodger. No one, we learn, can exist alone.

The fatal flaw of DiCKENSIAN was that it could not escape its cleverness. It wanted to tell a set of good stories, through engrossing characters, in a particularly televisual form. It did so, most successfully, but all the while it was inviting the viewer to see how ingeniously the pieces of the puzzle had been put together. There was an expectation, at least to a degree, that the viewer would be familiar with the novels, so that they would recognize the people involved and have a sense of their fate. Prequels can only be read with an understanding that their conclusion must be to arrive at the starting point of a story with which we are familiar. But despite countless film and television adaptations, and the familiarity of certain characters, the mass audience's grasp of why these characters came together in the way that they did was probably not all that Jordan might have hoped for.

Paradoxically, what hampered Dickensian was its allegiance to Dickens. No matter how widely the writer's imagination might range, the ending could only be to return to Dickens. The ownership conferred by originality never goes away. So it was that, despite good reviews and a fervent body of fans, DiCKENSIAN was not recommissioned by the BBC. This is surely a great loss, because there was every promise of Jordan's creation seeking out endings beyond what were Dickens's starting points. Jordan had storylined sixty episodes, pointing out that Dickens had created over 2,00o characters and so far he had only used around twenty five (Burrell 2015). Perhaps several 
such works of art remain unmade. It is as tragic as a burned manuscript, a what-might-have-been that could still be reality if only someone was braver, and the schedulers more consistent. In some alternative universe, DiCKENSIAN Series 2 and 3 can, perhaps, be seen, bringing delight at their ingenuity and pleasure at how they extend the art of a great novelist through characters that are owned by all of us. But not in this one.

\section{Notes}

1. This essay has been developed from a 2016 blog post, "Dickensian," on my personal site: http://lukemckernan.com/2016/04/22/dickensian.

2. Britain has a long tradition of debate, and scholarship, on the subject of literary adaptation for television. For an overview, see Cardwell (2002).

3. This painting, often reproduced, now belongs to the Dickens Museum in Britain. See https://en.wikipedia.org/wiki/Charles_Dickens\#/media/ File:Dickens_dream.jpg. A nineteenth-century American wood engraving echoes the contemporary belief that Dickens's characters possessed a life of their own: https://en.wikipedia.org/wiki/Charles_Dickens\#/media/ File:Charles_Dickens_characters.jpg.

4. The original broadcast dates (all BBC One) were: Episode 1: tx. December 26, 2015; 2: tx. December 26, 2015; 3: tx. December 27, 2015; 4: tx. December 27, 2015; 5: tx. January 1, 2016; 6: tx. January 6, 2016; 7: tx. January 7, 2016; 8: tx. January 13, 2016; 9: tx. January 14, 2016; 10: tx. January 21, 2016; 11: tx. January 22, 2016; 12: tx. January 27, 2016; 13: tx. January 28, 2016; 14: tx. February 4, 2017; 15: tx. February 5, 2017; 16: tx. February 11, 2016; 17: tx. February 12, 2016; 18: tx. February 18, 2016; 19: tx. February 19, 2016; 20: tx. February 21, 2016.

\section{References and Further Reading}

Ackroyd, Peter. 199o. Dickens. London: Sinclair-Stevenson.

Allen, Robert C. 1995. "Introduction." In To Be Continued...: Soap Operas Around the World, edited by Robert C. Allen, 17-24. London: Routledge.

Burrell, Ian. 2015. “Dickensian' Is the BBC's Biggest Christmas Offering: When Fagin Met Scrooge." The Independent, December 1, 2015. http://www.independent.co.uk/arts-entertainment/tv/features/dickensian-is-the-bbcs-biggest-christmas-offering-when-fagin-met-scrooge-a6756276. html.

Cardwell, Sarah. 2002. Adaptation, Revisited: Television and the Classic Novel. Manchester: Manchester University Press.

Dowell, Ben. 2015. "Soapy and silly - What the Dickens Is the BBC Up to in Its Latest Drama Series Dickensian?" Radio Times, December 26, 2015. http://www.radiotimes.com/news/2015-12-26/ soapy-and-silly-what-the-dickens-is-the-bbc-up-to-in-its-latest-drama-series-dickensian. 
Farber, Alex. 2016. "Festive Ratings Highlights: Sherlock, Dickensian \& Fungus." Broadcast, January 4, 2016. http://www.broadcastnow.co.uk/ratings/festive-ratings-highlights-sherlockdickensian-and-fungus/5098483.article.

Geraghty, Christine. 1995. "Social Issues and Realist Soaps: A Study of British Soaps in the 1980/199os." In To Be Continued.... Soap Operas Around the World, edited by Robert C. Allen, 70. London: Routledge.

Jordan, Tony. 2014. "I Turned Down the Chance to Research Charles Dickens for a TV Series Nine Times ... Then I Found a Kindred Spirit." The Independent, August 27, 2014. http://www. independent.co.uk/arts-entertainment/tv/features/tony-jordan-i-turned-down-the-chanceto-research-charles-dickens-for-a-tv-series-nine-times-then-i-9695398.html.

—. 2015a. BBC Media Centre, December 9, 2015.

—. 2015b. "Creating Dickensian." BBC Writers Room (blog), December 22, 2015. http://www.bbc. co.uk/blogs/writersroom/entries/29d1d218-a710-45ab-96c5-7ac9a6d86a87.

Knights, L.C. 1933. How Many Children Had Lady Macbeth?: An Essay in the Theory and Practice of Shakespeare Criticism. Cambridge: Gordon Fraser.

Martinson, Jane. 2016. "BBC Axes Dickensian after One Series.” The Guardian, April 21, 2016. https://www.theguardian.com/media/2016/apr/21/bbc-axes-dickensian-after-one-series.

McKernan, Luke. 2016. “Dickensian.” Luke Mckernan (blog). http://lukemckernan.com/2016/o4/22/ dickensian.

Pritchett, V.S. 1998. "Edwin Drood." In The Pritchett Century: The Selected Writings of V.S. Pritchett. London: Chatto \& Windus. 